\title{
Access of dynamics vegetation during Holocene by Poaceae pollen grains
}

\section{Opinion}

Paleoecological reconstructions by Poaceae pollen morphology were not easy until last years. Poaceae pollen was marker only grassland vegetations and no more ecological or taxonomic inferences from pollen samples of Quaternary. ${ }^{1,2}$ Though the pollen grains of the family Poaceae are widely found in Quaternary sediments, the Poaceae pollen has been low taxonomic resolution due to similar pollen morphology between species (monoporate and spheroidal pollen grains). However, studies on modern and fossil pollen grains of many species analyzed in the last years reveal more ecological inferences from Poaceae pollen, principally species of grassland of the South America, included Rio Grande do Sul state of Brazil. ${ }^{3-6}$ These works provide ecological information that may be important to the reconstruction of past vegetation, such as about forests, grasslands, herbaceous and arboreal species, $\mathrm{C} 3$ and $\mathrm{C} 4$ species (species with $\mathrm{C} 4$ metabolism are tropical and live in warmer and drier regions, while temperate species are $\mathrm{C} 3$ and live in humid and cold conditions). The difference between Poaceae pollen is about the size of pollen grains. ${ }^{3,4}$

Analysis about sizes of pollen grains of plants shows that forests species have a size larger than pollen of grassland species. ${ }^{3}$ Furthermore, some species showed diporate aperture that allows identifying palynomorphs of Poaceae in the high resolution ${ }^{6}$ (Figure 1). These studies provide modern Poaceae pollen dataset. After, we selected the one Quaternary sediment to analysis and identify fossil Poaceae pollen grains, which the fossil pollen may be identified by modern pollen dataset. The Quaternary sediment is from Águas Clara's region of southern Brazil (Figure 2) and the sediment has 2, $70 \mathrm{~m}$ depth and $10.975 \mathrm{C} 14 \mathrm{BP}$ of basal age (C14 BP-years before present by radiocarbon dating. Present is the years 1950). The samples were chemically processed according to the methodology proposed by Faegri and Iversen (1989) ${ }^{7}$ and the slides created using glycerinated jelly were deposited in the Laboratório de Palinologia da ULBRA. 60 Poaceae pollen grains were measured at intervals of $10 \mathrm{~cm}$. Results showed that Poaceae pollen reveals ecological information about dynamics of grassland and forest vegetation of Poaceae. Grassland was the vegetation dominates in the early Holocene and a low percentage of Poaceae forest species.

Changes are in the late Holocene (3.420years BP) when increasing the frequency of forest species. Poaceae pollen of forests was increasing more and more in percentage during the late Holocene. The samples of recent ages show similar percentages of both pollen grains of grassland and forest reflecting modern vegetation in the Águas Claras region. The new data of modern and fossil Poaceae pollen in this work documents that analysis of vegetation change in the past is possible by Poaceae pollen. The pollen grains of Poaceae species allowed shows events of climate changes. Larger pollen indicates humid conditions and expansion of forests while smaller pollen of grasslands is dominance in the samples of basal ages. The smaller Poaceae pollen of grassland species suggests dry conditions in the early Holocene. The new approach and the new Poaceae pollen database show that ecological information from Poaceae pollen is useful for reconstructions of vegetation with a high diversity of grasses, such as grasslands of Pampa biome from South America.

\author{
Volume I Issue 3 - 2017
}

\section{Jefferson Nunes Radaeski, Soraia Girardi Bauermann}

Laboratório de Palinologia da Universidade Luterana do BrazilLBRA, Universidade Luterana do Brazil, Brazil

Correspondence: Jefferson Nunes Radaeski, Laboratório de Palinologia da Universidade Luterana do Brazil-ULBRA, Universidade Luterana do Brazil, Brazil, Tel +55 5 I 347740 00, Email jefferson.radaeski@gmail.com

Received: August 31, 2017| Published:September 21, 2017

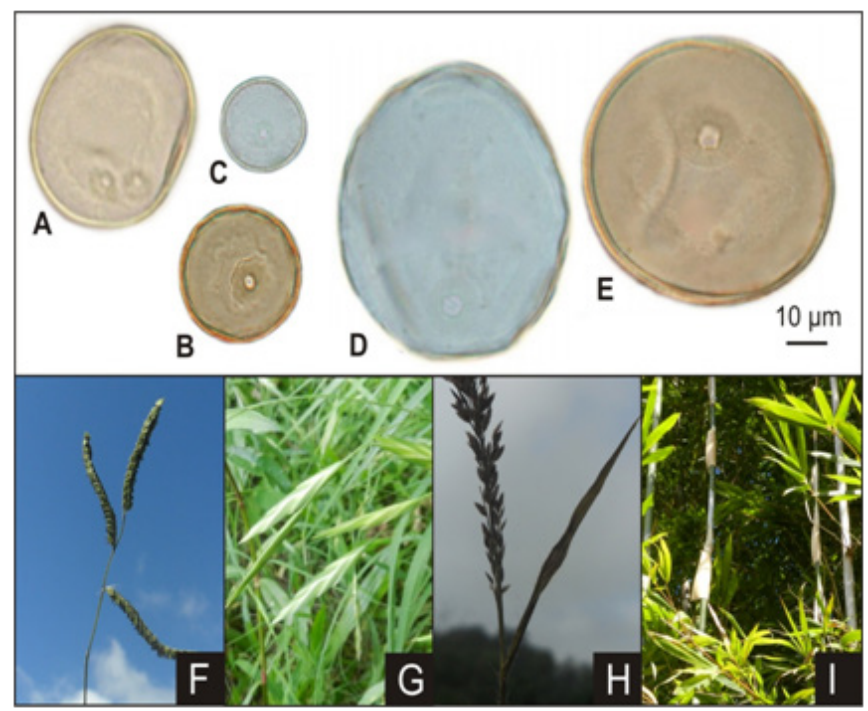

Figure I Different sizes of Poaceae pollen grains of grassland species (A-C) and forest species (D-E).

Diporate pollen grain of Paspalum pauciciliatum (A) and monoporate pollen grain of Aristida sp. (B), Eragrostis neesii (C), Guadua trinii (D) and Colanthelia cingulata (E). Poaceae plants of Paspalum pauciciliatum (F), Bromus catharticus $(\mathrm{G})$, Eragrostis neesii $(\mathrm{H})$ and Guadua trinii $(\mathrm{I})$.

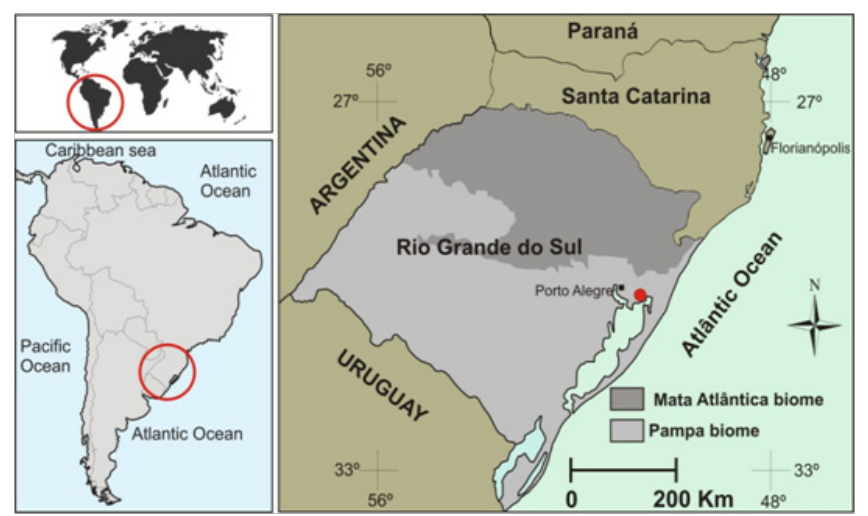

Figure 2 Map of southern Brazil showing the Quaternary sediment sampling site in Rio Grande do Sul, Brazil. 


\section{Acknowledgements}

None.

\section{Conflict of interest}

Author declares that there is no conflict of interest.

\section{References}

1. Bauermann SG. Análises palinológicas e evolução paleovegetacional e paleoambiental das turfeiras de Barrocadas e Águas Claras, Planície Costeira do Rio Grande do Sul, Brasil. Universidade Federal do Rio Grande do Sul, Porto Alegre, Brazil; 2003;137:1-8.

2. Behling H, Pillar V, Bauermann SG. Late Quaternary Araucaria forest, grassland (Campos), fire and climate dynamics, inferred from a high-resolution pollen record of Cambará do Sul in southern Brazil. Palaeogeogr Palaeoclimatol Palaeoecol. 2004;203:277-297.
3. Radaeski JN, Bauermann SG, Pereira AB. Poaceae Pollen from Southern Brazil: Distinguishing Grasslands (Campos) from Forests by Analyzing a Diverse Range of Poaceae Species. Front Plant Sci. 2016;7(1):1830-1833.

4. Schüler L, Behling H. Poaceae pollen grain size as a tool to distinguish past grasslands in South America: a new methodological approach. Veget Hist Archaeobot. 2011;20(2):83-96.

5. Jan F, Schüler L, Behling H. Trends of pollen grain size variation in C3 and C4 Poaceae species using pollen morphology for future assessment of grassland ecosystem dynamics. Grana. 2014;53(2):1-17.

6. Radaeski JN, Cunha DJ, Bauermann SG. Diporate Pollen Grains of Poaceae Species: High Pollen Resolution for Reconstruction of Grasslands Vegetation. J Agri Res. 2017;2(3):135-137.

7. Faegri K, Iversen J. Textbook of Pollen Analysis. John Wiley \& Sons, New York, USA; 1989. p. 328. 